\title{
The Correlates of Energy Management Practices and Sales Performance of Small Family Food Firms in Turkey
}

\author{
Adah-Kole Emmanuel Onjewu \\ Wolverhampton Business School, University of Wolverhampton, UK. \\ a.onjewu@wlv.ac.uk
}

\section{Elmar Puntaier}

School of Strategy and Leadership, Coventry University, UK.

elmar.puntaier@coventry.ac.uk

\author{
Sundas Hussain \\ Nottingham Business School, Nottingham Trent University, UK. \\ sundas.hussain@ntu.ac.uk
}

\begin{abstract}
Purpose

While pursuing energy management, firms simultaneously strive to boost sales as a path towards economic performance. Also, the literature suggests that family firms exhibit greater environmental commitment than their non-family counterparts. To examine these contentions, this review espouses contingency theory to interrogate the correlations of (1) energy consumption targets, (2) energy efficiency enhancing measures, (3) energy consumption monitoring and (4) the domestic sales performance of small family food firms in Turkey's food sector.
\end{abstract}

\section{Methodology}

Data were sourced from the World Bank Enterprise Survey. A sample of 137 family firms in food production, processing and retail was analysed using non-linear structural equation modelling. The net effects of path coefficients were estimated to determine the extent to which energy management practices predict domestic sales.

\section{Findings}

The path analysis revealed that although energy consumption targets do not directly increase sales performance, they stimulate firms' energy efficiency enhancement measures and energy consumption monitoring to produce this effect by $21 \%$.

\section{Practical/Managerial Implications}

The definitive results will reassure small family food firms of the financial and ecological benefits of setting energy targets in the first instance. This should be seen as a path towards putting in place energy efficiency enhancing measures and monitoring energy consumption. Insights for policy development are also offered to public stakeholders in the energy sector.

\section{Originality}


This inquiry is one of the first to examine energy management in the food sector at the family firm level through the contingency lens. Theoretically, the results draw attention and shed new light on disparate energy management practices and their discrete yet substantial contribution to sales performance. Practically, the fresh insights offer intelligence for the development of a national energy management policy in Turkey.

Keywords: Energy Consumption Targets; Energy Efficiency Enhancement Measures; Energy Consumption Monitoring; Family Firms; Small Food Business; Sales Performance; Turkey.

\section{Introduction}

Globally, there has been a longstanding international commitment to reduce energy consumption (Trotta, 2020), even prior to the Kyoto protocol of 1997 that extended the United Nations' 1992 climate change agenda (Yao et al., 2019). In recent times, momentum from the Paris Agreement of 2015 has further pricked public interest and research into energy management practices (Dong et al., 2018; Singh et al., 2019). Through its Energy Efficiency Directive, the European Union (or EU hereafter) has mandated member states to set energy consumption targets and instal energy management systems (Fresner et al., 2017). This follows evidence that reduced energy consumption results in lower carbon emissions and energy costs, and enhances the image of businesses (Giama and Papadopoulos, 2018). Energy management also has the effect of conserving resources as desired by small firms (Memili et al., 2018; Mokhtarzadeh et al., 2020; Jafari-Sadeghi et al., 2021).

Possibly, Capehart et al.'s (2016) depiction of energy management as the efficient and effective use of energy to maximise profits and enhance competitiveness best reflects the interest of the business enterprise. It invokes the longstanding view of rational economic behaviour and deems energy management to be an environmental cum profit-making undertaking that also yields competitive advantage (Dechant and Altman, 1994). As a practice, it encompasses the planning and maintenance of assets to achieve energy-efficient operations (Gordić et al., 2010), in small and large firms alike. Yet, in the small firm environment, the International Energy Agency (or IEA heareafter) determined that SMEs consume more than 13\% of global energy (IEA, 2015), and Raj and Kirubakaran (2021) write that electrical energy constitutes $30-40 \%$ of SMEs' production cost. Moreover, recognising that SMEs account for more than $90 \%$ of global firms (Taiwo et al., 2016), these undercurrents bring the energy management practices and performance of small firms into empirical focus.

A widely accepted measure of firm performance is the volume of sales arising from operations (Schwepker and Good, 2011); or sales performance. All things being equal, it is believed that the greater the sales performance of the firm, the more competitive it will be (Smyczek et al., 2019). Nevertheless, the source of sales has long been debated for its distinctive effect on operations (Ito and Pucik, 1993; Berman et al., 2015). Hence, Salomon and Shaver (2005) stress the distinction between domestic and foreign (or export) sales. On one hand, domestic sales are receipts that accrue to firms for 
products/services rendered to consumers within national borders (Sun and Anwar, 2015; Esteves et al., 2021). On the other hand, foreign sales are the percentage of export receipts redeemed by firms as a fraction of total sales (Estrin et al., 2008).

In addition to interrogating small as opposed to large firms, this inquiry observes the energy management practices and domestic sales performance of family businesses for three reasons. First, taking account of the ownership profile of small firms in general, family firms comprise $70-90 \%$ of businesses in the global economy (Maloni et al., 2017). Second, family firms have been known to demonstrate greater environmental commitment and responsible behaviour [like energy management] than non-family firms (Blodgett et al., 2011). Third, for the advancement of knowledge, prior studies have yet to assess the energy management of family firms not least in the food sector. This is especially surprising owing to the substantial volume of extant research interrogating energy management practices in the food industry (Muller et al., 2007; Paton et al., 2013; Corsini et al., 2016). Along these parameters, there are also indications that Turkey has a high density of small firms (Karadağ, 2016), many of which are in the food trade (Ozturk and Akoglu, 2020). Turkey is also an important context to study following suggestions that the country lacks a national management standard for energy consumption even though businesses account for $42 \%$ of its energy use (Ates and Durakbasa, 2012). The country's energy policy as articulated in its 'Vision 2023' strategy only addresses concerns around energy supply, prices and competitiveness (Aydın, 2020). A framework for promoting energy management across the country still seems remote.

Taking account of the extant literature, thus far, scholars have yet to address energy management practices at the level of small family food firms. Rather, they have investigated, for example, energy efficiency in the pulp and paper industry (Lawrence et al., 2018), energy management in manufacturing firms (Fernando and Hor, 2017) and supply chains (Fernando et al., 2018), as well as energy efficiency investment (Cooremans and Schönenberger, 2018). In terms of context, much of the energy management evidence has been reported from countries like the UK (Revell and Blackburn, 2007), Portugal (Catarino et al., 2015), Serbia (Gordić et al., 2010), Ireland (Cosgrove et al., 2017) and China (Chiu et al., 2012), to mention a few. Studies set in Turkey are relatively few, dated, and have scarcely considered the food sector. For instance, Ates and Durakbasa (2012) assessed energy management practices in the energy intensive iron, steel, cement, paper, ceramics, and textile industries, while Önüt and Soner's (2007) work was focused on manufacturers. In other inquiries, Ulutaş (2005) contemplated the geopolitical and political undercurrents of energy management in Turkey, whereas Hepbasli and Ozalp (2003) reviewed the historical and constitutional influences of energy practices. There are seemingly no occasions where small family firms have been isolated as the unit of analysis in Turkey nor elsewhere. Hence, this study is conceived to offer evidence of energy management from the overlooked population of small family firms in Turkey and the wider food sector. 
Pressing forward, the overarching question of this inquiry is: to what extent do discrete energy management practices increase sales performance? Accordingly, its aim and contributions are fivefold. From the outset, underpinned by the contingency theory, (1) it conceptualises a novel link between the energy management practices and domestic sales performance of small family food firms in Turkey. Next, for empirical specificity, (2) it separates and examines discrete energy management practices in the forms of (a) energy efficiency enhancing measures, (b) energy consumption targets and (c) energy consumption monitoring and their individual associations with domestic sales. Also, (3) it ranks, on the basis of path coefficients, how the alternate energy management practices increase sales performance. Furthermore, (4) it quantifies the extent to which the inherent energy management practices altogether predict the sales performance of firms in the sample. Finally, (5) to the best of the authors' knowledge, this investigation is the first to offer energy management evidence from small family food firms.

The rest of this paper is organised as follows. Section 2 describes the study context, while section 3 conceptualises the links between energy consumption targets, energy efficiency enhancing measures, energy consumption monitoring and domestic sales performance. Subsequently, section 4 explains the measurement variables, items and scales before the study's findings are presented in section 5 . In section 6 , the findings are compared and synthesised with prior literature by way of a discussion. In section 7 , the paper concludes with theoretical contributions, practical implications, and areas for future research.

\section{The Context of Turkey}

Economically, Turkey is the twentieth largest market in the world with a population of 84 million in 2020 (The World Bank, 2021a) and a GDP of \$720 billion (The World Bank, 2021b). It is considered a newly industrialised middle-income country (Selçuk and Öztürk, 2021), and operates a diversity of sectors including automotive manufacturing, consumer electronics and home appliances, banking, construction, textiles, agriculture, mining, food and tourism (Aslan and Topcu, 2018; Akcigit et al., 2020). Roughly $20 \%$ of GDP is provided by the food and beverage industry in Turkey, and it is the largest producer of dried figs, hazelnuts, raisins and dried apricots, as well as a world leading producer of honey, milk and dairy (Öztürk, 2021). In 2019 there was a 13.4\% increase in the formation of foodrelated enterprises (Turkstat, 2019), including retail and catering services registered as hotels, restaurants and cafes (Y1ldız and Tüysüz, 2019; Bucak and Yiğit, 2021). Some of the popular traditional foods consumed within and outside the country are Turkish Coffee, Dolma, Tarhana, Kebab, Baklava and Halva (Albayrak and Gunes, 2010). The motivation for investigating smaller rather than larger food businesses is driven by the obvious ubiquity of the former, and the peculiar lack of knowledge on family firms. Arguably, smaller firms dominating the Turkish business landscape have a role to play in the 
national energy management agenda at the same time as needing to sustain their operations. The IEA (2021, p.3) specified that 'to achieve a modern, competitive economy, Turkey needs to pay close attention to the sustainability of its energy sector and its longer-term carbon footprint', and 'establish energy management structures' for industrial enterprises (IEA, 2021, p.58). As a consequence, research into the energy management practices of small family food firms is timely for generating grassroots insights that may support the development of a national energy management framework for Turkey.

\section{Theoretical Background and Hypotheses Development}

\subsection{Contingency Theory}

There is a diversity of energy management practices that may be adopted by firms. Essentially, their perception of costs and benefits may lead them to undertake alternative activities in the mutual pursuit of energy efficiency and operational performance. To clarify this behaviour, it has long been understood that economic agents continuously assess their situation and adapt their practices to increase rent (Sargeant, 1993; Arthur, 1994). This is consistent with the contingency perspective which suggests that 'the most effective technique depends on the set of circumstances at a particular point in time' (Luthans and Stewart, 1977, p. 182). Contingency behaviour also warrants 'identifying and developing functional relationships between environmental, management and performance variables' (Luthans and Stewart, 1977, p. 183). In energy management terms, these contingent variables or practices may include energy auditing, energy saving measures, energy monitoring, management commitment, energy awareness and energy knowledge programmes (Kannan and Boie, 2003; Fernando and Hor, 2017; Mokhtarzadeh et $a l ., 2021)$. To adopt such sustainability practices, small firms require conclusive evidence that they will improve their long-term performance (Cote et al., 2008). In this vein, a contingency approach supports the capturing of multidisciplinary engineering, management, finance, housekeeping and architectural processes aimed at optimising firms' energy efficiency (Kannan and Boie, 2003; Lee et al., 2011). Prior studies (such as Kannan and Boie, 2003 and Fernando and Hor, 2017) have examined the correlations between energy management practices with energy efficiency and carbon reduction outcomes. Although the utility of measuring these environmental outcomes cannot be disputed, such investigations do not advance knowledge on firms' contingent rent seeking behaviour in the course of implementing energy management. Hence, the ensuing conceptualisation aims to address this gap by associating (1) energy consumption targets, (2) energy efficiency enhancing measures and (3) energy consumption monitoring with the domestic sales performance of small family food firms in Turkey. This premise is now developed by way of literature review in 3.2 through 3.6.

\subsection{Energy Consumption Targets and Sales Performance}

Energy consumption targets are typically voluntary or negotiated limits set by firms in their energy use (Price et al., 2010). These targets are aimed at increasing energy efficiency by driving action and motivating in-house compliance with energy management policy (IEA, 2017). Although consumption 
targets are mostly set at regional or national levels (Štreimikienė and Balezentis, 2016), it is not unusual for firms to set and work towards energy reduction goals (Price et al., 2010). The IEA (2007) outlines that these targets may take one of six forms: (1) energy intensity [a reduction in energy consumption per unit of activity], (2) energy consumption [a reduction in energy consumption relative to a base year], (3) policy progress [an increase in the impact of energy efficiency policies], (4) energy productivity [an increase in activity per unit of energy consumed], (5) energy elasticity [a reduction in the ratio of energy consumption growth to activity growth] and (6) transactional [an increase in the uptake of energy efficient goods/services]. In the food industry, Ma et al. (2012) report that energy consumption targets translate into the cumulative megawatt-hours of electrical energy, cubic metres of gas, kilolitres of fuel oil or tons of steam coal conserved over a given period. The basis for the first hypothesis is the contention that small firms are less likely to set energy consumption targets because of a belief that they have a low energy intensity (Lee, 2012), and a perception that the financial benefits of doing so are immaterial (Schaltegger and Csutora, 2012). To query this thinking, the following notion is tested:

\section{H1. Energy consumption targets are positively and directly related to sales performance}

\subsection{Energy Consumption Targets and Energy Efficiency Enhancement Measures}

The IEA's (2017) suggestion that energy consumption targets drive action and motivate in-house compliance with the energy management policy suggests that targets inspire the mechanisms for complementary energy management practices such as energy efficiency enhancement measures. By definition, energy efficiency enhancement measures refer to the methods by which firms expend less energy for the production of the same amount of goods or services (Heilala et al., 2011). In the food sector, opportunities for energy efficiency enhancement include fuel-saving steam systems, heat recovery operations and bioenergy/waste utilisation processes (Chowdhury et al., 2018). These initiatives are deemed to be cost effective as they improve firms' competitiveness and minimise their environmental impact (Fernando and Hor, 2017). Yet, there are often technical and financial barriers preventing firms from adopting energy efficiency enhancement measures (Palm and Thollander, 2010). For instance, the energy efficiency management of technological processes requires the creation of a common interface with real time operative information on project flow that may be beyond the reach and deployment of small firms (Teslyuk et al., 2018). Hence, in spite of the perceived benefits, small firms face barriers that may discourage their adoption of energy efficiency enhancing measures (Nagesha and Balachandra, 2006). Consistent with this discourse, the second hypothesis seeks to verify whether energy consumption targets are a catalyst for energy efficiency enhancement measures. Thus:

H2. Energy consumption targets are positively and directly related to energy efficiency enhancement measures

\subsection{Energy Consumption Targets and Energy Consumption Monitoring}


Similar to the preceding hypothesis, it is probable that energy consumption targets catalyse a further practice of energy consumption monitoring. According to Foulds et al. (2017), energy consumption monitoring are routinised behaviours for improving understanding of energy use patterns and drivers with the aid of multiple data points. In this vein, researchers concur that the intelligence derived from quantifying the current impact of energy consumption improves firms' environmental performance (Vijayaraghavan and Dornfeld, 2010; Lenz et al., 2017; Liu et al., 2020). Evidence from the Serbian food sector suggests that energy consumption monitoring may also make it possible to track consumption targets using appropriate equipment and software (Jovanović et al., 2017). Characteristically, these take the forms of information display terminals and cloud-enabled smart meters that enable the visualisation of energy consumption information (Al-Turjman et al., 2019). Al-Turjman et al. (2019, p. 141) further explain that 'real time feedback results in a significant behaviour change for energy consumption'. Firms can also access artificial intelligence solutions for energy monitoring that have the capacity to predict consumption based on current and historical environmental conditions (Ageed et al., 2021). The third hypothesis checks whether energy consumption targets also instigate the practice of energy consumption monitoring. Hence:

\section{H3. Energy consumption targets are positively and directly related to energy consumption monitoring}

\subsection{Energy Efficiency Enhancement Measures and Sales Performance}

Recalling that energy efficiency enhancement measures are the methods by which firms expend less energy for the production of the same amount of goods or services (Heilala et al., 2011), contingent behaviour implies that firms may instal mechanisms for energy efficiency without necessarily setting energy consumption targets. Once more, this evokes Cote et al. (2008) and Schaltegger and Csutora's (2012) view that unless there are obvious material benefits, firms are unlikely to undertake any form of energy management. This is especially true for small firms with negligible energy consumption (Lee, 2012). Other known barriers to energy efficiency enhancement measures have been stated as low energy prices, lack of finance and lack of a national plan for energy efficiency (Fernando and Hor, 2017). Yet, to verify the validity of these claims, there is a shortage of empirical works associating energy efficiency enhancing measures with sales performance or other material outcomes. Such evidence is needed to challenge the presumption that energy efficiency enhancement measures are not worthwhile. Accordingly, to clarify this debate, the fourth hypothesis investigates the presence and direction of correlations between energy efficiency enhancement measures and sales performance.

\section{H4. Energy efficiency enhancement measures are positively and directly related to sales performance}

\subsection{Energy Consumption Monitoring and Sales Performance}

Extending the contingency line of thinking, it is also probable that firms may undertake monitoring for energy efficiency without necessarily setting energy consumption targets. To reaffirm, Foulds et al. 
(2017) previously described energy consumption monitoring as routinised behaviours for improving understanding of energy use patterns and drivers with the aid of multiple data points. Irizar-Arrieta $e t$ $a l$. (2020, p. 3) explain that energy monitors capture and display real-time data of energy consumption in 'different metrics, both quantitative (kWh and economic value) and qualitative (glows in colours depending on the quantity of electricity used)'. Like energy efficiency enhancing measures, there is also a hesitance to undertake energy consumption monitoring because of financial constraints (Sundramoorthy et al., 2010). Providing evidence from the UK, the authors revealed that $69 \%$ of households would only instal energy monitoring equipment if the cost was 'below $£ 50$, and none would do so beyond $£ 300$ ' (Sundramoorthy et al., 2010, p. 4). Although this evidence is generated from households, they bear the greatest proximity to family firms as owner/managers generally enact their personal dispositions in the running of the small business (Michaelas et al., 1998; Sánchez-Báez et al., 2018). Similar to the fourth hypothesis, there are no studies associating energy consumption monitoring with sales performance or other material outcomes. Accordingly, the concluding hypothesis interrogates the presence and direction of correlations between energy consumption monitoring and sales performance.

\section{H5. Energy consumption monitoring is positively and directly related to sales performance}

Following this conceptualisation, observing the interplay of energy targets, efficiency measures and consumption monitoring will reveal the degree of contingency behaviour exuded by small family food firms, vis-à-vis their energy management routines and sales performance.

\section{Method}

\subsection{Data and Measures}

The data for this study were obtained from the 2019 firm-level survey undertaken by The World Bank (2021c) in Turkey. Analysis of such data is consistent with Jha and Bose (2020). From a dataset of 1,663 firms, the data was reduced by three criteria. First, only firms involved in food production, processing and retail were retained. Second, cases with less than $50 \%$ single family ownership were excluded in keeping with the cardinal definition of a family business (Ferrari, 2020). Third, firms with more than 250 employees were also removed to advance empirical interest in SMEs. In the end, 137 cases remained and were selected for analysis. For the measures, four variables were modelled namely (1) energy consumption targets (ENCTARG), (2) energy efficiency enhancing measures (ENEEMES), (3) energy consumption monitoring (ENCMONT) and (4) domestic sales performance (DOMSALE). Table 1 further outlines the measures.

Table 1: Measurement Details

\begin{tabular}{|l|l|l|}
\hline Variable & Item & Scale \\
\hline ENCTARG & $\begin{array}{l}\text { Over the last three years, did this establishment have targets for energy } \\
\text { consumption? }\end{array}$ & Yes/No \\
\hline ENEEMES & $\begin{array}{l}\text { Over the last three years, did this establishment adopt any measures to } \\
\text { enhance energy efficiency? }\end{array}$ & Yes/No \\
\hline
\end{tabular}




\begin{tabular}{|l|l|l|}
\hline ENCMONT & $\begin{array}{l}\text { Over the last three years, did this establishment monitor its energy } \\
\text { consumption? }\end{array}$ & Yes/No \\
\hline DOMSALE & $\begin{array}{l}\text { In the last complete fiscal year, what percentage of this establishment's } \\
\text { sales were national sales? }\end{array}$ & Continuous \\
\hline
\end{tabular}

\subsection{Sample Characteristics}

To reiterate, all 137 firms were small family food businesses with no more than 250 employees. $15 \%$ of the sample ranged between 50 to 250 employees; and there was only one firm at the upper threshold of 250. The vast majority, just under two-thirds (63.5\%) of the firms had 20 employees or lower. Regarding country representation, over three-quarters of cases were spread across Northeast Anatolia, Central East Anatolia, the Black Sea to the West and East and the largest city, Istanbul. Their main business activities were baked goods/bakery/bread production, diner/restaurant services, flour manufacturing/processing, fruit packaging, butter, cheese, milk and spices production, food retailing and wholesale.

Table 2: Description of Firm Size and Region

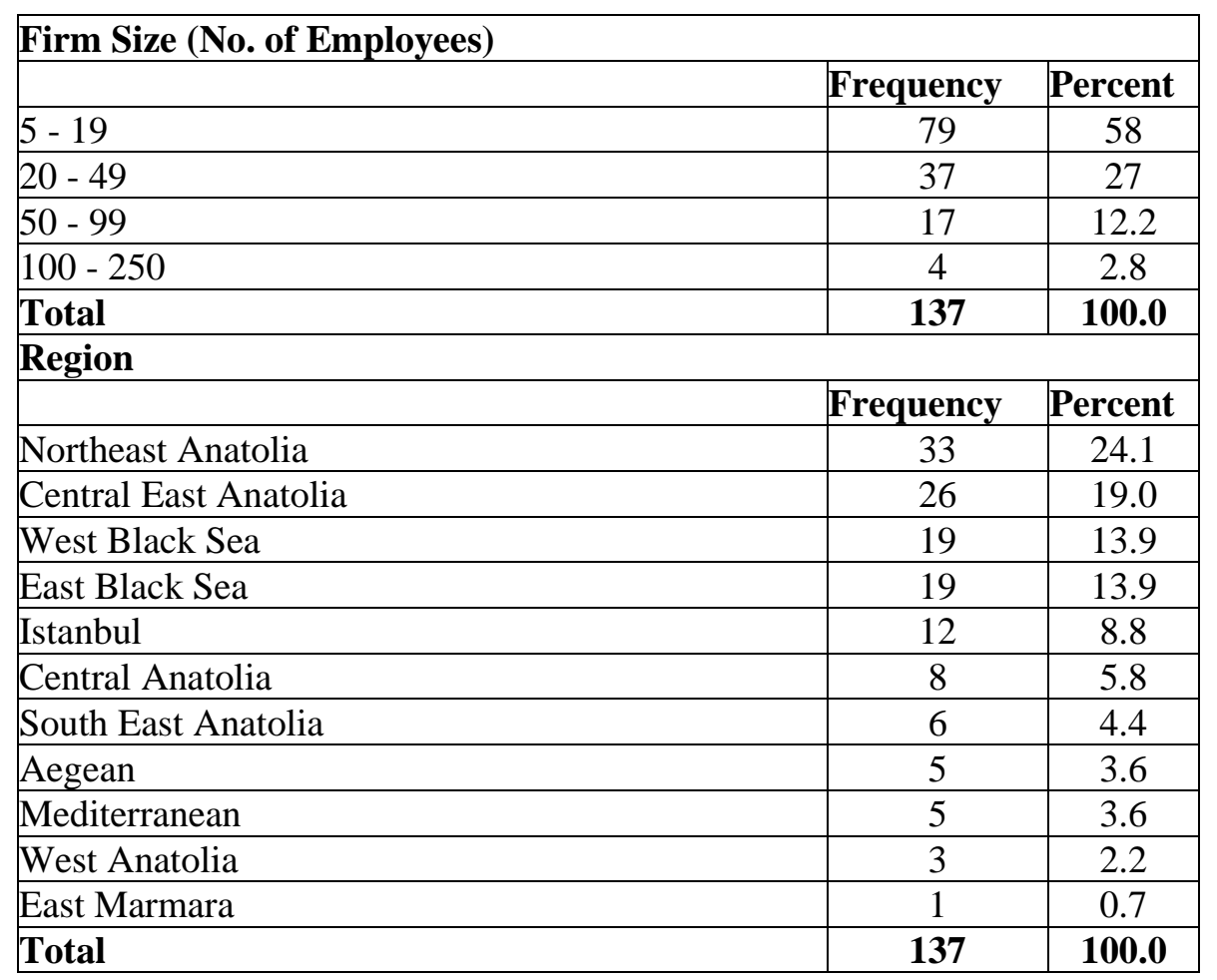

\section{Analysis}

For hypothesis testing, non-linear partial least squares structural equation modelling [PLS-SEM] was employed using Kock's (2019) WarpPLS software version 7.0. This technique was adopted for two reasons. First, Hair et al. (2017, p. 119) asserted that 'in a direct comparison with CB-SEM, the variance explained in the dependent variable is substantially higher in PLS-SEM'. Second, WarpPLS is suitable for testing binary data variables (Sajid et al., 2020).

\subsection{Measurement Model}


Before commencing path analysis, it is necessary to assess the reliability and validity of the variables. However, in the current study, all variables had single item indicators which negated the need to estimate composite reliability, Cronbach's alpha and average variance extracted (Loo, 2002). Yet, to ensure that they [the variables in the structural model] were not interchangeable, collinearity was calculated using variance inflation factor [VIF]. As shown in table 3, all VIF scores were below the 5 threshold suggested by Hair et al. (2011).

Table 3: Collinearity Diagnostic

\begin{tabular}{ccccc}
\hline & ENCTARG & ENEEMES & ENCMONT & DOMSALE \\
VIF & 1.687 & 1.141 & 1.684 & 1.068 \\
\hline
\end{tabular}

\subsection{Structural Model and Hypothesis Testing}

The structural model is tested using the path coefficients $(\beta)$ and $p$-values of the associations. The results are shown in figure 1.

Figure 1: Structural Model

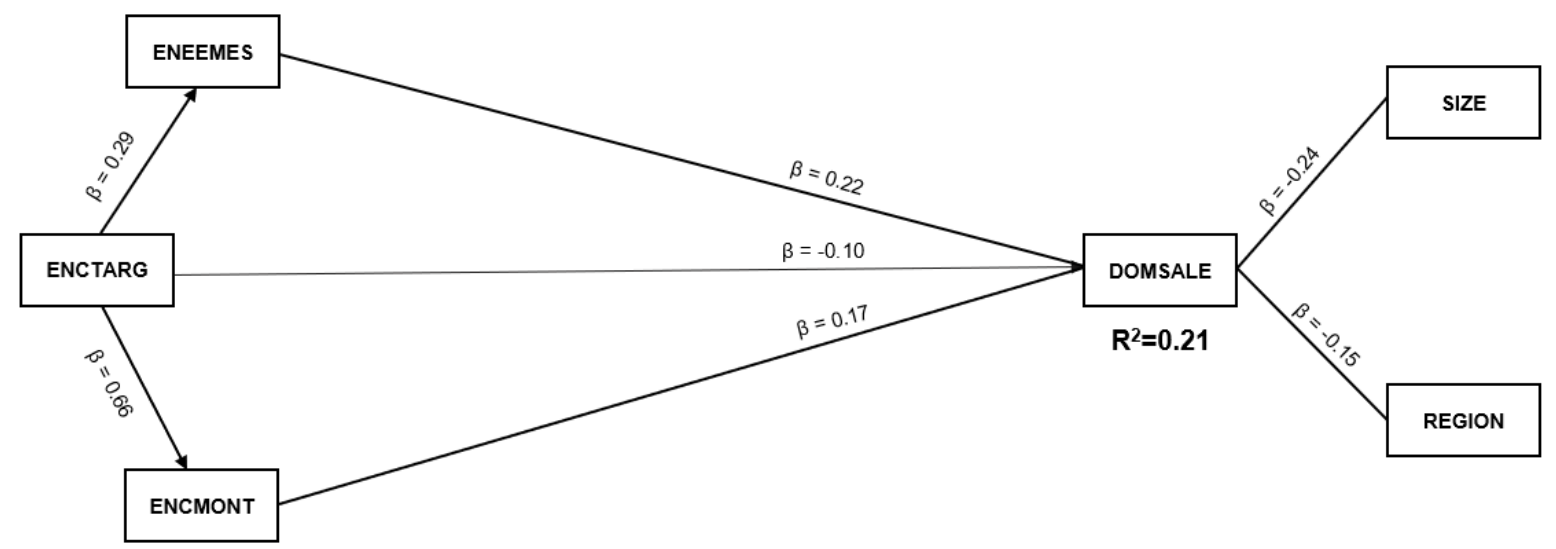

Assessing the inner model, the path analysis shows that the firms' setting of energy consumption targets has an insignificant relationship with domestic sales ( $p$-value $=0.11)$. However, setting energy consumption targets significantly increases energy efficiency enhancing measures $(\beta=0.29)$ and energy consumption monitoring $(\beta=0.66)$. In turn, these latter factors indirectly but substantially increase domestic sales $[\beta=0.22$ for energy efficiency enhancing measures and $\beta=0.17$ for energy consumption monitoring]. The two control variables of region $(\beta=-0.15)$ and firm size $(\beta=-0.24)$ were significant but negatively correlated to domestic sales. In terms of the indirect effects, both energy efficiency enhancing measures and energy consumption monitoring significantly and positively mediate the link between energy consumption targets and domestic sales ( $p$-value $=0.01, \beta=0.17$ [sum of indirect effects]). All paths considered, the model explained 21\% variance in the domestic sales performance of the firms in the sample. 
Table 4: Hypothesis testing

\begin{tabular}{|l|c|c|c|}
\hline Hypothesised Relationship & Path Coefficient & $\boldsymbol{P}$-Value & Test \\
\hline H1. ENERGY CONSUMPTION TARGETS $\Rightarrow$ SALES PERFORMANCE & -0.10 & 0.11 & $\begin{array}{c}\text { Non } \\
\text { significant, } \\
\text { Rejected. }\end{array}$ \\
\hline $\begin{array}{l}\text { H2. ENERGY CONSUMPTION TARGETS } \Rightarrow \text { ENERGY EFFICIENCY } \\
\text { ENHANCEMENT MEASURES }\end{array}$ & 0.29 & $\begin{array}{c}\text { Significant, } \\
\text { Not } \\
\text { Rejected. }\end{array}$ \\
\hline $\begin{array}{l}\text { H3. ENERGY CONSUMPTION TARGETS } \Rightarrow \text { ENERGY } \\
\text { CONSUMPTION MONITORING }\end{array}$ & 0.66 & $<.01$ & $\begin{array}{c}\text { Significant, } \\
\text { Not } \\
\text { Rejected. }\end{array}$ \\
\hline $\begin{array}{l}\text { H4. ENERGY EFFICIENCY ENHANCEMENT MEASURES } \Rightarrow \text { SALES } \\
\text { PERFORMANCE }\end{array}$ & 0.22 & $\begin{array}{c}\text { Significant, } \\
\text { Not } \\
\text { Rejected. }\end{array}$ \\
\hline $\begin{array}{l}\text { H5. ENERGY CONSUMPTION MONITORING } \Rightarrow \text { SALES } \\
\text { PERFORMANCE }\end{array}$ & 0.17 & 0.02 & $\begin{array}{c}\text { Significant, } \\
\text { Not } \\
\text { Rejected. }\end{array}$ \\
\hline
\end{tabular}

\section{Discussion}

To reiterate, the results have shown that although energy consumption targets are not effective for increasing domestic sales performance, they have a stimulating effect on energy efficiency enhancement measures and energy consumption monitoring, which indirectly improve domestic sales performance. On the whole, the findings confirm Mezias et al.'s (2020, p. 4) belief that family businesses 'pursue sustainability not because it is good for the world but because it is profitable'. Reverting to the contingency theory by which firms adapt their practices to increase rent (Sargeant, 1993; Arthur, 1994), the results are now discussed by describing (1) the indirect effect of energy consumption targets in 6.1, and (2) the effect of energy efficiency enhancement measures and energy consumption monitoring in 6.2 .

\subsection{The Indirect Effect of Energy Consumption Targets}

The path analysis showed that energy consumption targets only have an indirect association with domestic sales performance. This is an important finding that corroborates the IEA's (2017) view that energy consumption targets are effective for driving action and motivating in-house compliance with energy management policy. Particularly, the analysis also showed that energy consumption targets are directly and positively correlated with energy efficiency enhancing measures and energy consumption monitoring. Therefore, it can be said that energy consumption targets are not an end but a pathway to adopting other energy management practices. Conceivably, this is also recognised by the EU as it set itself a target of achieving 27\% improvement in energy efficiency across the bloc by 2030 (Bye et al., 2018). A contiguous target also includes generating 32\% of renewable energy by 2030 (Monti and Romera, 2020). The wider implication of such targets is explained by Reuter et al.'s (2019) suggestion 
that energy targets are not self-fulfilling or mutually exclusive as they also impact on energy consumption behaviour. Furthermore, the indirect influence of energy consumption targets on sales performance through the contingent energy management practices supports Śmiech and Papież's (2014, p. 118) determination that 'energy policy targets influence linkages between energy consumption and economic growth'. Ultimately, energy consumption targets set at national and regional levels need to be cascaded to industrial sectors and households for realisation through national energy efficiency action plans [in the case of the EU] (Monti and Romera, 2020; Trotta, 2020) or similar programmes. For the food sector, agriculture, logistics, catering and manufacturing activities have intensified and exponentially increased global energy consumption in terms of Mtoe $^{1}$ (Ma et al., 2012; Dorcheh et al., 2021). Yet, when food firms are incentivised to set energy targets explicitly addressing the megawatthours of electrical energy, cubic metres of gas, kilolitres of fuel oil or tons of steam coal conserved, they are more likely to directly pursue energy efficiency and monitoring, and indirectly improve their domestic sales performance.

\subsection{The Effect of Energy Efficiency Enhancement Measures and Energy Consumption}

\section{Monitoring}

As also shown in the path analysis, there are significant and positive effects of energy efficiency enhancing measures and energy consumption monitoring on sales performance, as stimulated by energy consumption targets. Beginning with the distinct impact of energy efficiency enhancement measures on domestic sales performance, this finding suggests that small family food firms in the sample have overcome barriers such as the lack of finance and the lack of a national energy efficiency plan (Fernando and Hor, 2017). The evidence also proves that material benefits accrue from installing energy enhancement measures for small family food firms in the context, as per the condition described by Cote et al., (2008) and Schaltegger and Csutora (2012). Categorically, it can be said that deploying energy efficiency enhancement measures is financially worthwhile for small family food firms in Turkey, not discounting the likely environmental contribution also arising from this factor. Furthermore, reflecting on the impact of energy consumption monitoring, firms' likelihood to undertake this energy management practice was conceptualised by householders' hesitance (Sundramoorthy $e t$ al., 2010), as they are very often the owner/managers of small family food businesses. Consistent with Al-Turjman et al. (2019), it can be deduced that the data derived from energy consumption monitoring incites a behavioural change in the operations of small family food firms that manifests in higher domestic sales performance. Indeed, Irizar-Arrieta et al. (2020) describe one such behavioural change as they found that the automated monitoring of energy consumption through dashboards helps users avoid the forgetfulness of leaving devices switched on. Heiskanen et al. (2020) maintain that behavioural changes occur at the organisational, geographic and practical levels, and these modes of intervention overlap to achieve energy management.

\footnotetext{
${ }^{1}$ Million tonnes of oil equivalent
} 
To conclude, the next section presents the highlights and contributions of the study.

\section{Conclusion}

This study sought to determine the extent to which discrete energy management practices increase the sales performance of small family food firms based on contingency theory. The analysis suggests that when firms set energy consumption targets, they are likely to implement energy efficiency enhancing measures and undertake energy consumption monitoring to a degree that increases their domestic sales performance. Notwithstanding the lack of direct association between energy consumption targets and domestic sales performance [ $p$-value $=0.11$ ], on the whole, the path model predicted $21 \%$ of the latter. By comparison, energy efficiency enhancing measures increase domestic sales performance $[\beta=0.22]$ a little more than energy consumption monitoring $[\beta=0.17]$. The interplay of the factors show that energy consumption targets, energy efficiency enhancing measures and energy consumption monitoring are valid contingent practices that support rent-seeking behaviour. The paper concludes by considering the theoretical and practical implications arising, the study's limitations and opportunities for future research.

\subsection{Theoretical and Practical Implications}

On the theoretical level, the novel and mostly significant associations in the path model signal new avenues for scholars to investigate the net effects of energy management practices on a range of outcomes beyond domestic sales performance. For instance, first, there is a suggestion that the environmental perception of foreign consumers has a bearing on exporting firms' operations (Haddoud et al., 2021). Therefore, new knowledge can be advanced by examining the correlations between the inherent energy management practices and small family food firms' export performance. Second, the energy management practices can also be examined in parallel with firms' strategic commitment to environmental issues. Such orientation has been found to lower operational costs and increase performance (Peng and Lin, 2008; Marcus and Fremeth, 2009). Third, this inquiry also provokes interest into how energy management practices interrelate with the product and process innovation activities of small family food firms. In this regard, both De Massis et al. (2013) and Nieto et al. (2015) indicate that, compared to non-family firms, family firms take a different approach in their pursuit of product and process innovation. Finally, the contingency lens leaves room to capture further antecedents in small family food firms' technical, managerial, ownership, operational/architectural configuration and stakeholders' influence (Boudlaie et al., 2020) that may also interact with or predict the propensity for energy management.

For practitioners, the inherent findings demonstrate that there are firm-specific material benefits arising from adopting energy management practices. And, although small firms such as family food businesses may have low energy intensities, they can improve their sales performance by setting energy targets, 
installing energy efficiency enhancing measures and embarking on energy consumption monitoring. As corporate citizens, this also bodes well for their environmental performance especially in light of the cumulative effect of small family firms across the country adopting sustained energy management. More so, it is now clear that the operational and financial commitment of energy management is offset by the rewards of improved sales performance in the near term. Public stakeholders in Turkey such as the Ministry of Energy and Natural Resources, the General Directorate of Energy Affairs and affiliate institutions can reflect on these findings to develop a coherent national energy management policy for small firms. They can take a leaf from Taiwan's book where energy users are required to conduct an energy audit, set energy consumption targets and report their annual energy savings via an online energy declaration system (Hong et al., 2010). Such initiatives are especially relevant to Turkey and its ambitions to join the EU which requires member states to set up a national energy efficiency action plan (Monti and Romera, 2020; Trotta, 2020).

\subsection{Limitations}

This study is a single sector and single country investigation. Accordingly, the results may not reflect what obtains for small family firms in other sectors in Turkey, or for small family food firms in countries even with a similar socioeconomic profile. It is also noted that the World Bank data investigated is cross-sectional. As a result, the relationships in the path model are mostly associations which means causality should be interpreted with caution. In addition, the variables in the path are mostly binary and this could potentially weaken the observed relationships. The PLS-SEM approach taken also has the limitation of restricting the testing of theory (Hair et al., 2011), hence the application of the contingency perspective is only reflective.

\subsection{Future Research}

To address the aforesaid limitations, first, scholars may replicate the path model in the non-food sector and among small non-family food firms in Turkey, as well as in neighbouring states and other middleincome countries. Second, future studies can remedy the issue of cross-sectionality by taking a longitudinal approach that will equally address endogeneity concerns. Third, to strengthen the measurement of observed relationships, future research can include Likert-based measures to capture the intensity of the energy management practices more holistically. Fourth, studies taking a qualitative approach [such as multi-criteria decision making (Mokhtarzadeh et al., 2020) or Delphi technique (Rezaei et al., 2021)] are invited to validate the current findings in Turkey by probing contingent questions such as: What are the energy consumption targets set by small family food firms? What are the energy efficiency enhancing measures put in place by small family food firms? What kinds of energy consumption monitoring equipment, software and data are used by small family food firms? Are small family food firms aware of the increase in domestic sales arising from their energy management practices? What behavioural changes ensue from small food firms' energy consumption monitoring? 
Corroborated by this study, research into these areas will help small family food firms in the specific context to sell more Turkish delight.

\section{Acknowledgement}

We thank the World Bank Group for making the data available. All the analysis, interpretations and conclusions drawn are entirely and solely those of the authors.

\section{References}

Ageed, Z., Zeebaree, S., Sadeeq, M., Abdulrazzaq, M., Salim, B., Salih, A., Yasin, H. and Ahmed, A. (2021), 'A state of art survey for intelligent energy monitoring systems', Asian Journal of Research in Computer Science, Vol. 8, No. 1, pp.46-61.

Akcigit, U., Akgunduz, Y., Cilasun, S., Ozcan-Tok, E. and Yilmaz, F. (2020), 'Facts on business dynamism in Turkey', European Economic Review, Vol. 128 No. C, pp. 1-30.

Albayrak, M. and Gunes, E. (2010), 'Traditional foods: Interaction between local and global foods in Turkey, African Journal of Business Management, Vol. 4 No. 4, pp.555-561.

Al-Turjman, F., Altrjman, C., Din, S. and Paul, A. (2019), 'Energy monitoring in IoT-based ad hoc networks: An overview, Computers \& Electrical Engineering, Vol. 76, pp.133-142, doi.org/10.1016/j.compeleceng.2019.03.013.

Arthur, W. (1994), 'Bounded rationality and inductive behavior', American Economic Review, Vol. 84 No. 2, pp. 406-411.

Aslan, A. and Topcu, E. (2018), 'The relationship between export and growth: Panel data evidence from Turkish sectors', Economies, Vol. 6 No. 2, pp. 1-15.

Ates, S. and Durakbasa, N. (2012), 'Evaluation of corporate energy management practices of energy intensive industries in Turkey', Energy, Vol. 45 No. 1, pp.81-91.

Aydın, C. (2020), 'Nuclear energy debate in Turkey: Stakeholders, policy alternatives, and governance issues', Energy Policy, 136(C), doi.org/10.1016/j.enpol.2019.111041.

Berman, N., Berthou, A. and Héricourt, J. (2015), 'Export dynamics and sales at home', Journal of International Economics, Vol. 96 No. 2, pp. 298-310.

Blodgett, M., Dumas, C. and Zanzi, A. (2011), 'Emerging trends in global ethics: A comparative study of US and international family business values'. Journal of Business Ethics, Vol. 99 No. 1, pp.29-38.

Boudlaie, H., Mahdiraji, H., Shamsi, S., Jafari-Sadeghi, V. and Garcia-Perez, A. (2020), 'Designing a human resource scorecard: An empirical stakeholder-based study with a company culture perspective', Journal of Entrepreneurship, Management and Innovation, 16(4), 113-147.

Bucak, T. and Yiğit, S. (2021), 'The future of the chef occupation and the food and beverage sector after the COVID-19 outbreak: Opinions of Turkish chefs', International Journal of Hospitality Management, 92, p.102682. doi.org/10.1016/j.ijhm.2020.102682. 
Bye, B., Fæhn, T. and Rosnes, O. (2018), 'Residential energy efficiency policies: Costs, emissions and rebound effects', Energy, Vol. 143 No. C, pp.191-201.

Capehart, B., Turner, W. and Kennedy, W. (2020), Guide to Energy Management, Gistrup, River Publishers.

Catarino, J., Henriques, J. and Egreja, F. (2015), 'Portuguese SME toward energy efficiency improvement', Energy Efficiency, Vol. 8 No. 5, pp. 995-1013.

Chiu, T., Lo, S. and Tsai, Y. (2012), 'Establishing an integration-energy-practice model for improving energy performance indicators in ISO 50001 energy management systems', Energies, Vol. 5 No. 12 , pp. 5324-5339.

Chowdhury, J., Hu, Y., Haltas, I., Balta-Ozkan, N., Matthew, G. and Varga, L. (2018), 'Reducing industrial energy demand in the UK: A review of energy efficiency technologies and energy saving potential in selected sectors', Renewable and Sustainable Energy Reviews, Vol. 94 , pp. 1153 - 1178, doi.org/10.1016/j.rser.2018.06.040.

Cooremans, C. and Schönenberger, A. (2019), 'Energy management: A key driver of energyefficiency investment?', Journal of Cleaner Production, Vol. 230, pp. 264-275. doi.org/10.1016/j.jclepro.2019.04.333.

Corsini, A., Bonacina, F., Feudo, S., Lucchetta, F. and Marchegiani, A. (2016), 'Multivariate KPI for Energy Management of Cooling Systems in Food Industry, Energy Procedia, Vol. 100 No.101, pp.297-304.

Cosgrove, J., Doyle, F., Littlewood, J. and Wilgeroth, P. (2017), 'A methodology for electricity monitoring and targeting $(M \& T)$ in an Irish precision engineering SME', International Journal of Sustainable Engineering, Vol. 10 No. 4-5, pp. 233-240.

Cote, R., Lopez, J., Marche, S., Perron, G. and Wright, R., (2008), 'Influences, practices and opportunities for environmental supply chain management in Nova Scotia SMEs', Journal of Cleaner Production, Vol. 16 No. 15, pp.1561-1570.

De Massis, A., Frattini, F. and Lichtenthaler, U. (2013), 'Research on technological innovation in family firms: present debates and future directions', Family Business Review, Vol. 26 No. 1, pp. $10-31$.

Dechant, K. and Altman, B. (1994), 'Environmental leadership: from compliance to competitive advantage', Academy of Management Perspectives, Vol. 8 No. 3, pp.7-20.

Dorcheh, F., Hajiagha, S., Rahbari, M., Jafari-Sadeghi, V. and Mahdiraji, H. (2021), 'Identification, analysis and improvement of red meat supply chain strategies considering the impact of COVID19 pandemic: a hybrid SWOT-QSPM approach in an emerging economy', British Food Journal, Vol. ahead-of-print No. ahead-of-print. https://doi.org/10.1108/BFJ-09-2020-0865

Esteves, P., Portela, M. and Rua, A. (2021), 'Does Domestic Demand Matter for Firms' Exports?', Open Economies Review. doi.org/10.1007/s11079-021-09623-9.

Estrin, S., Meyer, K., Wright, M. and Foliano, F. (2008), 'Export propensity and intensity of subsidiaries in emerging economies', International Business Review, Vol. 17 No. 5, pp. 574-586.

Fernando, Y. and Hor, W. (2017), 'Impacts of energy management practices on energy efficiency and carbon emissions reduction: A survey of malaysian manufacturing firms, Resources, Conservation \& Recycling, Vol. 126, pp.62-73. dx.doi.org/10.1016/j.resconrec.2017.07.023.

Fernando, Y., Bee, P., Jabbour, C. and Thomé, A. (2018), 'Understanding the effects of energy management practices on renewable energy supply chains: Implications for energy policy in emerging economies', Energy Policy, Vol. 118, pp.418-428. doi.org/10.1016/j.enpol.2018.03.043.

Ferrari, F. (2020), 'Exploring the side effects of socio-emotional wealth. A multilevel analysis approach to the dysfunctional dynamics in family business succession, International Journal of Entrepreneurship and Small Business, Vol. 40 No. 1, pp. 128-146.

Foulds, C., Robison, R. and Macrorie, R. (2017), 'Energy monitoring as a practice: Investigating use of the iMeasure online energy feedback tool', Energy Policy, Vol. 100 No. 104, pp. 194-202.

Gordić, D., Babić, M., Jovičić, N., Šušteršič, V., Končalović, D. and Jelić, D. (2010), 'Development of energy management system-case study of Serbian car manufacturer. Energy Conversion and Management', Vol. 51 No. 12, pp. 2783-2790. 
Gordić, D., Babić, M., Jovičić, N., Šušteršič, V., Končalović, D. and Jelić, D. (2010), 'Development of energy management system-Case study of Serbian car manufacturer', Energy Conversion and Management, Vol. 51 No. 12, pp.2783-2790.

Haddoud, M., Onjewu, A. and Nowiński, W. (2021), 'Environmental commitment and innovation as catalysts for export performance in family firms', Technological Forecasting \& Social Change. doi.org/10.1016/j.techfore.2021.121085.

Hair, J., Matthews, L., Matthews, R. and Sarstedt, M. (2017), 'PLS-SEM or CB-SEM: updated guidelines on which method to use', International Journal of Multivariate Data Analysis, Vol. 1 No. 2, pp.107-123.

Hair, J., Ringle, C. and Sarstedt, M. (2011), 'PLS-SEM: Indeed a Silver Bullet', Journal of Marketing Theory and Practice, Vol. 19 No. 2, pp. 139-152.

Heilala, J., Klobut, K., Salonen, T., Järvinen, P. and Shemeikka, J. (2011), 'Energy Use Parameters for Energy Efficiency Enhancement in Discrete Manufacturing Process', Intelligent Computation in Manufacturing Engineering, pp. 1 - 5.

Heiskanen, E., Matschoss, K., Laakso, S. and Apajalahti, E. (2019), A critical review of energy behaviour change: The influence of context, In Lopes, M., Antunes, C., Janda, K. (Eds.) 'Energy and Behaviour: Towards a Low Carbon Future', pp. 391-417, Massachusetts, Academic Press.

Hepbasli, A. and Ozalp, N. (2003), 'Development of energy efficiency and management implementation in the Turkish industrial sector', Energy Conversion and Management, Vol. 44 No. 2, pp. 231-249.

Hong, G., Su, T., Lee, J., Hsu, T. and Chen, H. (2010), 'Energy conservation potential in Taiwanese textile industry', Energy Policy, Vol. 38 No. 11, pp. 7048-7053.

IEA (2015), Accelerating Energy Effciency in Small and Medium-sized Enterprises, Paris, International Energy Agency.

IEA (2017), Setting Energy Efficiency Targets, Paris, International Energy Agency.

IEA (2021), Turkey 2021 Energy Policy Review, Paris, International Energy Agency.

Irizar-Arrieta, A., Casado-Mansilla, D., Garaizar, P., López-de-Ipiña, D. and Retegi, A. (2020), 'User perspectives in the design of interactive everyday objects for sustainable

behaviour', International Journal of Human-Computer Studies, 137, p.102393. doi.org/10.1016/j.ijhcs.2019.102393.

Ito, K. and Pucik, V., (1993). R\&D spending, domestic competition, and export performance of Japanese manufacturing firms. Strategic Management Journal, Vol. 14 No. 1, 61-75.

Jafari-Sadeghi, V., Mahdiraji, H., Bresciani, S. and Pellicelli, A. (2021), 'Context-specific microfoundations and successful SME internationalisation in emerging markets: A mixed-method analysis of managerial resources and dynamic capabilities', Journal of Business Research, Vol. 134, 352-364. https://doi.org/10.1016/j.jbusres.2021.05.027.

Jha, A. and Bose, I. (2020), 'Linking drivers and outcomes of innovation in IT firms: The role of partnerships', Information Systems Frontiers, pp. 1-15. doi.org/10.1007/s10796-020-10061-0.

Jovanović, B., Filipović, J. and Bakić, V. (2017). Energy management system implementation in Serbian manufacturing-Plan-Do-Check-Act cycle approach. Journal of Cleaner Production, Vol. 162, pp.1144-1156. doi.org/10.1016/j.jclepro.2017.06.140.

Kannan, R. and Boie, W. (2003), 'Energy management practices in SME - case study of a bakery in Germany', Energy Conversion and Management, Vol. 44 No. 6, pp. 945-959.

Karadağ, H. (2016), 'The role of SMEs and entrepreneurship on economic growth in emerging economies within the post-crisis era: An analysis from Turkey', Journal of Small Business and Entrepreneurship Development, Vol. 4 No. 1, pp. 22-31.

Kock, N. (2019), WarpPLS User Manual: Version 7.0, Texas, ScriptWarp Systems.

Lawrence, A., Karlsson, M. and Thollander, P. (2018), 'Effects of firm characteristics and energy management for improving energy efficiency in the pulp and paper industry', Energy, Vol. 153, pp. 825-835. doi.org/10.1016/j.energy.2018.04.092.

Lee, K. (2012), 'Carbon accounting for supply chain management in the automobile industry', Journal of Cleaner Production, Vol. 36, pp.83-93. doi.org/10.1016/j.jclepro.2012.02.023. 
Lee, S., Teng, M., Fan, K., Yang, K. and Horng, R. (2011), 'Application of an energy management system in combination with FMCS to high energy consuming IT industries of Taiwan', Energy Conversion and Management, Vol. 52 No. 8-9, pp. 3060-3070.

Lenz, J., Kotschenreuther, J. and Westkaempera, E. (2017), 'Energy Efficiency in Machine Tool Operation by Online Energy Monitoring Capturing and Analysis', Procedia CIRP, Vol. 61, pp. 365-369, pp. doi.org/10.1016/j.procir.2016.11.202.

Liu, X., Liu, X., Luo, X., Fu, H., Wang, M. and Li, L. (2020). Impact of Different Policy Instruments on Diffusing Energy Consumption Monitoring Technology in Public Buildings: evidence from Xi'an, China. Journal of Cleaner Production, Vol. 251, p.119693. doi.org/10.1016/j.jclepro.2019.119693.

Loo, R. (2002), 'A caveat on using single-item versus multiple-item scales, Journal of Managerial Psychology, Vol. 17 No. 1, pp. 68-75.

Luthans, F. and Stewart, T. (1977), 'A general contingency theory of management', Academy of Management Review, Vol. 2 No. 2, pp. 181-195.

Ma, C., Chen, M. and Hong, G. (2012), 'Energy conservation status in Taiwanese food industry', Energy Policy, Vol. 50 No. C, pp. 458-463.

Maloni, M., Hiatt, M. and Astrachan, J. (2017), "Supply management and family business: A review and call for research", Journal of Purchasing and Supply Management, Vol. 23 No. 2, pp. 123136.

Marcus, A. and Fremeth, A. (2009), 'Green Management Matters Regardless', Academy of Management Perspectives, Vol. 23, No. 3, pp. 17-26.

Memili, E., Fang, H., Koc, B., Yildirim-Öktem, Ö. and Sonmez, S. (2018). Sustainability practices of family firms: The interplay between family ownership and long-term orientation. Journal of Sustainable Tourism, Vol. 26 No. 1, pp. 9-28.

Mezias, S., Pant, I. and Abzug, R., 2020. Sustainability in Asia: Family Business at the Forefront. INSEAD Working Paper No. 2020/38/EFE. 10.2139/ssrn.3370819

Michaelas, N., Chittenden. F. and Poutziouris P. (1998), 'A model of capital structure decision making in small firms', Journal of Small Business and Enterprise Development, Vol. 5 No. 3, pp. 246-60.

Mokhtarzadeh, N., Mahdiraji, H., Jafarpanah, I., Jafari-Sadeghi, V. and Cardinali, S. (2020), 'Investigating the impact of networking capability on firm innovation performance: using the resource-action-performance framework', Journal of Intellectual Capital, Vol. 21 No. 6, pp. $1009-1034$.

Mokhtarzadeh, N., Mahdiraji, H., Jafarpanah, I., Jafari-Sadeghi, V. and Bresciani, S. (2021), 'Classification of inter-organizational knowledge mechanisms and their effects on networking capability: a multi-layer decision making approach', Journal of Knowledge Management, Vol. 25 No. 7, pp. 1665-1688.

Mokhtarzadeh, N., Mahdiraji, H., Jafari-Sadeghi, V., Soltani, A. and Kamardi, A. (2020), 'A producttechnology portfolio alignment approach for food industry: a multi-criteria decision making with z-numbers', British Food Journal, Vol. 122 No. 12, pp. 3947-3967.

Monti, A. and Romera, B. (2020), 'Fifty shades of binding: appraising the enforcement toolkit for the EU's 2030 renewable energy targets, Review of European, Comparative \& International Environmental Law, Vol. 29 No. 2, pp.221-231.

Muller, D., Marechal, F., Wolewinski, T. and Roux, P. (2007), 'An energy management method for the food industry', Applied Thermal Engineering, Vol. 27 No. 16, 2677-2686.

Nagesha, N. and Balachandra, P. (2006), 'Barriers to energy efficiency in small industry clusters: Multi-criteria-based prioritization using the analytic hierarchy process', Energy, Vol. 31 No. 12, pp. $1969-1983$.

Nieto, M., Santamaria, L. and Fernandez, Z. (2015), 'Understanding the innovation behaviour of family firms', Journal of Small Business Management, Vol. 53, No. 2, pp. 382-399.

Önüt, S. and Soner, S. (2007), 'Analysis of energy use and efficiency in Turkish manufacturing sector SMEs', Energy Conversion and Management, Vol. 48 No. 2, pp. 384-394.

Ozturk, S. and Akoglu, A. (2020), 'Assessment of local food use in the context of sustainable food: A research in food and beverage enterprises in Izmir, Turkey', International Journal of Gastronomy and Food Science, 20, p.100194. doi.org/10.1016/j.ijgfs.2020.100194. 
Öztürk, Y. (2021), Food Production in Turkey and Opportunities for Swiss SMEs, Zürich, Switzerland Global Enterprise.

Palm, J. and Thollander, P. (2010), 'An interdisciplinary perspective on industrial energy efficiency, Applied Energy, Vol. 87 No. 10, pp. 3255-3261.

Paton, J., Khatir, Z., Thompson, H., Kapur, N. and Toropov, V. (2013). Thermal energy management in the bread baking industry using a system modelling approach. Applied Thermal Engineering, Vol. 53 No. 2, pp. 340-347.

Peng, Y. and Lin, S. (2008), 'Local responsiveness pressure, subsidiary resources, green management adoption and subsidiary's performance: Evidence from Taiwsanese manufacturers', Journal of Business Ethics, Vol. 79, No. 1-2, pp. 199-212.

Price, L., Wang, X. and Yun, J. (2010), 'The challenge of reducing energy consumption of the Top1000 largest industrial enterprises in China', Energy Policy, Vol. 38 No. 11, pp. 6485-6498.

Raj, L. and Kirubakaran, V. (2021), 'Energy efficiency enhancement and climate change mitigations of SMEs through grid-interactive solar photovoltaic system', International Journal of Photoenergy, doi.org/10.1155/2021/6651717.

Reuter, M., Patel, M. and Eichhammer, W. (2019), 'Applying ex post index decomposition analysis to final energy consumption for evaluating European energy efficiency policies and targets', Energy Efficiency, Vol. 12 No. 5, pp.1329-1357.

Revell, A. and Blackburn, R. (2007), 'The business case for sustainability? An examination of small firms in the UK's construction and restaurant sectors', Business Strategy and the Environment, Vol. 16 No. 6, pp. 404-420.

Rezaei, M., Jafari-Sadeghi, V., Cao, D. and Mahdiraji, H. (2021), 'Key indicators of ethical challenges in digital healthcare: A combined Delphi exploration and confirmative factor analysis approach with evidence from Khorasan province in Iran', Technological Forecasting and Social Change, Vol. 167 No. C, pp. 120724.

Sajid, M., Muhammad, N., Zakaria, R., Shahbaz, A. and Nauman, A. (2020), 'Associated Factors of Cardiovascular Diseases in Pakistan: Assessment of Path Analyses Using Warp Partial Least Squares Estimation', Pakistan Journal of Statistics and Operation Research, Vol. 16 No. 2, pp. 265-277.

Salomon, R. and Shaver, J. (2005), 'Export and domestic sales: Their interrelationship and determinants, Strategic Management Journal, Vol. 26 No. 9, pp. 855-871.

Sánchez-Báez, E., Fernández-Serrano, J. and Romero, I. (2018), 'Personal values and entrepreneurial attitude as intellectual capital: impact on innovation in small enterprises', Amfiteatru Economic, Vol. 20 No. 49, pp.771-787.

Sargent, T. (1993), 'Bounded rationality in macroeconomics: The Arne Ryde memorial lectures', Oxford, Oxford University Press.

Schaltegger, S. and Csutora, M. (2012), 'Climate accounting and sustainability management', Journal of Cleaner Production, Vol. 36, pp.1-12. doi.org/10.1016/j.jclepro.2012.06.024.

Schwepker, C. and Good, D. (2011), 'Moral judgment and its impact on business-to-business sales performance and customer relationships', Journal of Business Ethics, Vol. 98 No. 4, pp. 609-625.

Selçuk, B. and Öztürk, M. (2021), The political economy of Turkey in the last two centuries. In The Routledge Handbook on Contemporary Turkey (pp. 269-281). Routledge.

Śmiech, S. and Papież, M. (2014), 'Energy consumption and economic growth in the light of meeting the targets of energy policy in the EU: The bootstrap panel Granger causality approach', Energy Policy, Vol. 71, pp.118-129. doi.org/10.1016/j.enpol.2014.04.005.

Smyczek, S., Festa, G., Rossi, M. and Monge, F. (2019), 'Economic sustainability of wine tourism services and direct sales performance-emergent profiles from Italy, British Food Journal, Vol. 122 No. 5, pp.1519-1529.

Streimikienè, D. and Balezentis, T. (2016), Kaya identity for analysis of the main drivers of GHG emissions and feasibility to implement EU "20-20-20" targets in the Baltic States, Renewable and Sustainable Energy Reviews, Vol. 58 No. C, pp.1108-1113.

Sun, S. and Anwar, S. (2016), 'Interrelationship among foreign presence, domestic sales and export intensity in Chinese manufacturing industries', Applied Economics, Vol. 48 No. 26, pp. $2443-$ 2453. 
Sundramoorthy, V., Liu, Q., Cooper, G., Linge, N. and Cooper, J. (2010), 'DEHEMS: A user-driven domestic energy monitoring system', Internet of Things - Institute of Electrical and Electronics Engineers, pp. 1-8.

Taiwo, J., Falohun, T. and Edwin, A. (2016), 'SMEs Financing and its Effects on Nigerian Economic Growth', European Journal of Business, Economics and Accountancy, Vol. 4 No. 4, pp. 37-54.

Teslyuk T., Tsmots I., Teslyuk V., Medykovskyy M. and Opotyak Y. (2018) Architecture and Models for System-Level Computer-Aided Design of the Management System of Energy Efficiency of Technological Processes at the Enterprise. In: Shakhovska N., Stepashko V. (eds) Advances in Intelligent Systems and Computing II. CSIT 2017. Advances in Intelligent Systems and Computing, Vol. 689, pp. 538-557. Springer, Cham.

The World Bank (2021a), Population Total - Turkey, Washington DC, The World Bank Group.

The World Bank (2021b), GDP - Turkey, Washington DC, The World Bank Group.

The World Bank (2021c), Enterprise Surveys, Washington, The World Bank Group.

Trotta, G. (2020), 'Assessing drivers of energy consumption and progress toward energy targets in Italy, Energy Sources, Part B: Economics, Planning, and Policy, Vol. 15 No. 3, pp. 137-156.

Turkstat (2021), Entrepreneurship and Business Demography, 2017-2019, Available online: data.tuik.gov.tr/Bulten/Index?p=Entrepreneurship-and-Business-Demography-2017-2019-33939 [Accessed 21 June 2021].

Ulutaş, B. (2005), 'Determination of the appropriate energy policy for Turkey', Energy, Vol. 30 No. 7, pp. 1146-1161.

Vijayaraghavan, A. and Dornfeld, D. (2010), 'Automated energy monitoring of machine tools', CIRP Annals, Vol. 59 No. 1, pp. 21-24.

Yao, X., Huang, R. and Song, M. (2019), 'How to reduce carbon emissions of small and medium enterprises (SMEs) by knowledge sharing in China', Production Planning \& Control, Vol. 30 No. 10-12, pp. 881-892.

Yıldız, N. and Tüysüz, F. (2019), 'A hybrid multi-criteria decision making approach for strategic retail location investment: Application to Turkish food retailing', Socio-Economic Planning Sciences, Vol. 68 No. C, pp. 1-25. 